\title{
EFEKTIVITAS PENGGUNAAN MODEL PEMBELAJARAN PROBING-PROMPTING TERHADAP HASIL BELAJAR SISWA TEMA LINGKUNGAN SAHABAT KITA DI KELAS V SEKOLAH DASAR
}

\author{
Angga Setiawan \\ anggasetiawan25.as@gmail.com \\ PGSD, STKIP PGRI Trenggalek
}

\begin{abstract}
Abstrak: Keberhasilan yang dicapai oleh siswa tidak terlepas dari peran dari seorang pendidik, masalah yang timbul kurangnya pemahaman pendidik dalam menguasai suatu model pembelajaran sehingga berdampak kearah kurang optimalnya hasil belajar siswa. Peneliti berupaya memberikan solusi dengan menggunakan model pembelajaran probing-prompting untuk meningkatkan hasil belajar siswa. Penelitian yang dilakukan oleh peneliti memiliki tujuan untuk melihat efektivitas penggunaan model pembelajaran probing-prompting terhadap hasil belajar siswa pada tema Lingkungan Sahabat Kita di kelas V Sekolah Dasar. Peneliti menggunakan metode kuantitatif dalam penelitiannya jenis penelitian yang digunakan yaitu quasy eksperimen. Populasi dan sampel keseluruh siswa kelas V dengan jumlah 17 siswa. Data yang diperoleh dengan observasi, pretest (tes awal) tujuannya untuk mendapatkan data yang berupa hasil belajar siswa pada waktu sebelum diberikan perlakuan atau model pembelajaran saat itu dan posttest (tes akhir) untuk mendapatkan data yang berupa hasil belajar siswa setelah mendapatkan perlakuan atau model pembelajaran. Instrumen penelitian menggunakan tes. Analisis data menggunakan Independent $t$-Test, Hasil Independent $t$-Test pada hasil belajar diperoleh thitung > ttabel yaitu 3,29>2,09 dengan melihat taraf signifikansi 0,05 Sedangkan pengaruh variabel bebasnya yaitu dengan menggunakan model pembelajaran probing-prompting terhadap variabel terikatnya yaitu hasil belajar dengan nilai $76,7 \%$. Maka didapatkan hasil sebagai berikut, $\mathrm{H}_{\mathrm{a}}$ diterima dan $\mathrm{H}_{0}$ ditolak. Sehingga kesimpulan dari data yang diperoleh oleh peneliti maka ada pengaruh yang signifikan model pembelajaran probing-prompting terhadap hasil belajar siswa tema lingkungan sahabat kita di kelas V Sekolah Dasar.
\end{abstract}

Kata kunci: model pembelajaran, model probing-prompting, hasil belajar.

\section{THE EFFECTIVENESS OF USING THE PROBING-PROMPTING LEARNING MODEL ON STUDENT LEARNING OUTCOMES IN THE THEME OF OUR FRIEND'S ENVIRONMENT IN CLASS V ELEMENTARY SCHOOLS}


Angga. Efektivitas Penggunaan Model Pembelajaran...

Abstract: The success achieved by students cannot be separated from the role of an educator, the problem that arises is the lack of understanding of educators in mastering a learning model so that it has an impact towards less than optimal student learning outcomes. Researchers try to provide solutions by using the probing-prompting learning model to improve student learning outcomes. Research conducted by researchers aims to see the use of the probing-prompting learning model on student learning outcomes on the theme Our Friends of the Environment in grade V Elementary School. Researchers used quantitative methods in their research. The type of research used was the brush experiment. Population and sample of all students in grade $V$ with a total of 17 students. The data obtained by observation, the pretest (pre-test) aims to obtain data in the form of student learning outcomes at the time before being given treatment or the current learning model and posttest (final test) to obtain data in the form of learning outcomes after receiving treatment or learning models. The research instrument used a test. Data analysis using t-test, the results of t-test on learning outcomes obtained tcount $>$ ttable, namely 3.29> 2.09 by looking at the significance level of 0.05, while the effect of the independent variables is by using the probing-prompting learning model on the variables it shows, namely study with a value of $76.7 \%$. Then the following results are obtained, $\mathrm{Ha}$ is accepted and $\mathrm{HO}$ is rejected. So the conclusion from the data obtained by the researcher, there is a significant effect of the probing-prompting learning model on student learning outcomes with the theme of our friend's environment in grade $V$ Elementary School.

Keywords: learning model, probing-prompting model, learning outcomes.

\section{PENDAHULUAN}

Pendidikan awal memberikan bekal kepada peserta didik untuk membentuk karakternya yang nantinya berguna untuk diterapkan saat terjun di masyarakat, jenjang awal pendidikan dimulai dari sekolah dasar sampai dengan perguruan tinggi. Realitanya saat ini pendidikan yang diperoleh oleh peserta didik saat menginjak sekolah dasar belum terciptanya suatu indikasi yang merujuk kepada pembelajaran yang memaksimalkan semua aspek dalam proses pembelajaran, antara lain aspek kognitif yang berupa pengetahuan, aspek afektif yang berupa sikap atau perilaku dan yang terakhir adalah aspek psikomotor yang berupa keterampilan, ketiga aspek ini wajib dituntaskan oleh peserta didik sesuai dengan kurikulum K13 (Hamdu \& Lisa, 2012). Ketercapaian ketiga aspek tersebut bisa diketahui dari hasil belajar yang diperoleh siswa selama mengikuti proses pembelajaran, apabila dari salah satu ketiga aspek tersebut nilai yang didapatkan kurang maka dikatakan hasil belajar siswa kurang optimal. Sesuai dengan Undang-Undang Nomor 20 tahun 2003 tentang Sistem Pendidikan Nasional, Pasal 3, tujuan pendidikan nasional adalah mengembangkan potensi peserta didik yang berakhlak mulia, berilmu, kreatif, 
Angga. Efektivitas Penggunaan Model Pembelajaran...

mandiri, dan menjadi warga negara yang demokratis dan bertanggung jawab. Sekolah sebagai pelaksana pendidikan sangat berpengaruh dan tentu saja menjadi lahan utama sebagai sasaran dari semua pihak baik orang tua, masyarakat dan jajaran birokrasi juga mendapatkan dampak secara langsung. Guru juga ikut berperan penting dalam pembelajaran di Sekolah, oleh karena itu diperlukan proses belajar mengajar yang optimal dan kondusif. Tugas dari pendidikan sangat penting didalam memanajemen kelas agar suasana proses pembelajaran menjadi lebih kondusif, sehingga akan meningkatkan hasil belajar yang optimal.

Pada saat proses pembelajaran pendidik dituntut untuk lebih kreatif dan inovatif untuk memperlancar dan memberikan kemudahan untuk dalam memahamkan materi kepada siswanya, dengan kreativitas dan inovasi dari guru maka dapat menciptakan proses pembelajaran yang menyenangkan dan peserta didik merasa lebih terbantu untuk memahami setiap materi yang dijelaskan oleh guru, materi itu tidak hanya sekedar diserap tetapi bisa lebih diterapakan pada dunianya sehari-hari inilah proses pembelajaran yang bermakna untuk siswa. Pendidik berupaya untuk selalu memberikan cara agar siswa dapat memusatkan terhadap proses pembelajaran yang berlangsung pada saat itu. Maka dari itu dibutuhkan pendukung yang efektif antara lain: model, metode, strategi, pendekatan dan teknik pembelajaran. Cara pendidik dalam mengajar tidak terlepas dari yang namanya suatu model pembelajaran yang tentunya mempunyai ciri khas dan kelebihannya masingmasing setiap model pembelajaran. Hasil observasi awal dan wawancara yang dilakukan peneliti menunjukkan bahwa sebagian guru dalam melaksanakan pembelajaran menggunakan model STAD. Dalam hal ini ada beberapa masalah yang timbul yaitu model STAD masih terikat oleh kemampuan guru dan siswa menjadi kurang aktif dalam pembelajaran. Permasalahan ini mengakibatkan hasil belajar siswa masih kurang optimal.

Permasalahan di atas perlu diadakan perbaikan dalam kegiatan pembelajaran, pendidik berupaya untuk selalu memberikan kesempatan kepada peserta didik untuk mampu aktif dalam setiap proses pembelajaran dari awal sampai akhir dan menyajikan suatu masalah yang nyata bagi siswa. Pendidik memberikan solusi yang tepat dalam proses pembelajaran yang salah satunya menggunakan model pembelajaran agar pemahaman materi yang diserap oleh peserta didik akan lebih mudah untuk dipahami dan peningkatan hasil belajar akan terasa dan terlihat nantinya. Peningkatan hasil belajar tidak terlepas dari kemauan siswa dalam mengikuti proses pembelajaran yang baik yang dibantu oleh 
Angga. Efektivitas Penggunaan Model Pembelajaran...

kreativitas guru untuk memberikan materi pembelajaran dengan menggunakan berbagai model pembelajaran, hal ini menjadi salah satu indikator dalam mencapai tujuan pendidikan yang dapat diketahui dari pencapaian tujuan pengajaran yang maksimal.

Upaya peneliti dengan menggunakan model pembelajaran Probing-Prompting diaharapkan menjadi salah satu upaya peneliti untuk memberikan dampak yang positif dalam meningkatkan mutu hasil belajar dalam pembelajaran tematik 2013. Proses pembelajaran Probing-Prompting, pembelajaran yang diawali dengan pengajuan masalah atau soal dari peserta didik berdasarkan informasi yang sudah ada. Pada pelaksanaannya pembelajaran ini membantu peserta didik dalam merumuskan suatu masalah berdasarkan topik atau materi yang sudah dijelaskan guru agar hal tersebut lebih mendalam disertai dengan solusi pemecahannya (Agus, Gading \& Dibia, 2017). Model pembelajaran Probing-Prompting mempunyai kelebihan untuk peserta didik yaitu mampu meningkatkan hasil belajar siswa, tidak membuat siswa mudah putus asa dalam memahami materi pembelajaran, menambah kepercayaan diri peserta didik dalam mengikuti diskusi antara teman dan guru dan meninngkatkan wawasan pemikirannya terhadap pemecahan permasalahan yang terjadi. Berdasarkan latar belakang yang telah dipaparkan dan dijelaskan oleh peneliti, maka diadakanlah penelitian yang berjudul "Efektivitas Penggunaan Model Pembelajaran Probing-Prompting Terhadap Hasil Belajar Siswa Tema Lingkungan Sahabat Kita di Kelas V Sekolah Dasar".

Model pembelajaran sesuai dengan realitanya memiliki peran yang sangat penting tentunya dalam meninkatkan keberhasilan pembelajaran, model merupakan suatu bentuk yang mewakili keakuratan sebagai proses yang aktual dan memungkinkan seorang individu atau kelompok merasa ingin melakukan suatu aktivitas sesuai dengan model tersebut. Model pembelajaran itu sendiri adalah suatu rentetan dalam proses pembelajaran yang dirancang oleh guru yang mempunyai pola yang dijadikan suatu pedoman pembelajaran di kelas atau tutorial dalam pembelajaran untuk menentukan suatu perangkat pembelajaran (Trianto, 2011).

Istilahnya Probing merupakan suatu hal yang berkaitan dengan penyelidikan dan pemeriksaan, sementara Prompting merupakan identik dengan dorongan atau tuntunan. Pengertian Probing jika ditinjau dari proses pembelajaran di dalam kelas adalah teknik yang diberikan oleh guru untuk membimbing peserta didiknya dalam menggunakan pengetahuan yang dikuasainya atau keterampilan berpikir yang telah ada pada dirinya 
Angga. Efektivitas Penggunaan Model Pembelajaran... dengan berkomunikasi guna memahami gejala atau keadaan yang sedang diamati sehingga terbentuk pengetahuan baru (Teguh, Kasdi \& Wahyu, 2019). Model pembelajaran tersebut siswa bisa terlatih kemampuan komunikasi, maka dalam proses pembelajaran peserta didik selalu dibiasakan untuk berani memberikan pendapatnya atas jawaban yang sudah diajukannya, serta memberikan komentar yang positif dan membangun atas jawaban yang diberikan oleh teman satu kelas dan gurunya, sehingga apa yang sedang dipelajari menjadi lebih bermakna baginya (Thobroni, 2015). Pendidik dalam pembelajaran sesuai dengan model probing prompting mempunnyai posisi sebagai guru fasilitator yaitu membimbing dan mengarahkan siswa dalam setiap memahami materi yang diajarkan pada saat itu, pendidik mempunyai peran dalam mendukung siswa untuk memahami berbagai konsep materi dengan cara mempersiapkan pada suatu situasi dan kondisi dengan pokok bahasan yang dijelaskan, setelah itu, peserta didik mencoba mengkontruksi permasalahan yang mucul dengan sebanyak mungkin yang berguna dalam rangka mendalami lebih jauh mengenai konsep tersebut. Sedangkan siswa diposisi tersebut yaitu sebagai subjek di dalam proses pembelajaran Probing-Prompting, karena pembelajaran ini bersifat student centred dimana siswa merupakan pusat pembelajaran. Siswa harus berperan aktif dalam merumuskan dan mencari solusi atas pertanyaan-pertanyaan (Abdurokhim, 2015). Pendidik harus memperhatikan situasi dalam menggunakan model pembelajaran ProbingPrompting karena kelas akan cenderung gaduh disebabkan pembelajaran lebih banyak ditekankan pada kegiatan diskusi, selain itu alokasi waktu juga harus diperhitungkan guru dengan baik, penggunaan bahasa juga sangat berpengaruh pada saat perumusan pertanyaan dan menganalisis solusi. Untuk itu guru sangat berperan pada saat menjadi fasilitator, diperlukan kemampuan pengorganisasian kelas yang baik bagi guru dengan demikian pembelajaran Probing-Prompting akan berjalan dengan baik.

Pembelajaran Probing-Prompting Mempunyai ciri-ciri antara lain: (1) peserta didik memperoleh ilmu dari proses belajarnya dari pendidik ataupun sebaliknya, (2) pendidik menganggap bahwasannya peserta didik merupakan rekan diskusinya untuk dilibatkan dan distimulus pola pemikiran peserta didik secara kritis dan tidak mendiskriminasi satu sama lain antara pendidik dan peserta didik, (3) peserta didik dapat mengembangkan cara berpikirnya untuk memahami secara jauh dan kritis pada dirinya sendiri dan lingkungan tempat tingggalnya, (4) model Probing-Prompting selalu berupaya untuk memaparkan sesuatu yang menjadi bahasan mengenai rahasia realita yang menantang bagi peserta didik 
Angga. Efektivitas Penggunaan Model Pembelajaran...

dan memaksa untuk diberikan suatu kritikan dan saran terhadap tantangan yang menjadi suatu persoalan didalam publik (Kusuma, 2020). Kritik dan saran yang diutarakan oleh peserta didik terhadap persoalan yang ada didalam publik akan membuka wawasan atau pengetahuan peserta didik untuk berdedikasi sebagai manusia seutuhnya.

Sintaks model pembelajaran Probing-Prompting bisa diketahui dengan memahami secara utuh ke enam tahapan teknik probing yang selanjutnya dikembangkan dengan prompting yaitu: 1) peserta didik dihadapkan pada suatu kondisi yang belum mereka ketahui misalnya pendidik memberikan situasi yang mengandung permasalahan yang menyangkut lingkungan, kehidupan sehari-harinya dan berita-berita saat ini dengan menggunakan gambar, artikel atau video, 2) pendidik merumuskan pertanyaan yang nantinya diajukan kepada siswa sesuai topik permasalahan yang sudah ditentukan dengan meninjau tujuan pembelajaran atau indikator pembelajaran, 3) pendidik membimbing diskusi peserta didik dalam merumuskan jawabannya dari pertanyaan yang diajukan dan memberikan kesempatan keseluruh peserta didik untuk berargumen sesuai dengan gagasan yang telah ditemukannya, 4) pendidik bisa menunjuk siswa secara langsung atau sesuai dengan absensi siswa untuk menjawab pertanyaan apabila peserta didik ragu-ragu untuk menjawab, 5) guru tetap membimbing siswa untuk memberikan argument atau pendapatnya, apabila jawaban yang diajukan oleh peserta didik sesuai dan benar, selanjutnya pendidik memberikan kesempatan yang lain untuk memberikan komentar, saran dan kritik guna untuk memberikan kenyakinan kepada seluruh siswa bahwasannya semua ikut andil untuk mengajukan argument dan pendapatnya sehingga siswa tidak merasa didiskriminasi dengan situasi ini, akan tetapi apabila peserta didik mengalami ketidakpahaman jawaban atau jawaban kurang sesuai, maka pendidik langsung memberikan pertanyaan lain atau bantuan pertannyaan yang merujuk pada penyelesaian jawaban dari topik persoalan. Setelah itu, pendidik memberikan pertanyaan-pertanyaan sesuai dengan tinngkatan yang lebih tinggi untuk melatih siswa dalam meningkatkan keterampilan berpikir kritisnya, jawaban-jawaban yang diberikan siswa merupakan bentuk ketercapaian indikator dalam suatu kompetensi dasar materi pembelajaran. Pertanyaan yang diajukan oleh pendidik tidak hanya untuk satu siswa atau yang pintar saja tetapi seluruh siswa, agar mereka merasa terlibat dalam kegiatan probing-prompting, 6) ketercapaian indikator pembelajaran benar-benar akan terlihat apabila seluruh siswa mampu memberikan argument dan pendapatnya secara berbeda-beda dari persoalan yang 
Angga. Efektivitas Penggunaan Model Pembelajaran... diberikan oleh guru, karena dengan ini siswa bisa lebih memamhami situasi dan kondisi sekarang. Selanjutnya sintaks yang dikembangkan dalam prompting itu sendiri bisa dipahami dari ketiga langkah ini yaitu: 1) menuliskan kembali pertanyaan yang sudah diajukan sesuai pemahaman peserta didik, 2) mengaplikasin pertanyaan secara singkat, jelas dan relevan sesuai pertanyaan awal, 3) membimbing dan menjelaskan informasi agar seluruh peserta didik mampu menjawab. Dengan sintaks Probing-Prompting itu sendiri proses tanya jawab yang dilakukan oleh peserta didik diharuskan secara acak, sehingga peserta didik yang lain bisa lebih siap dan sigap untuk berpartisipasi secara aktif, karena seluruh siswa dilibatkan dalam setiap tanya jawab di dalam proses pembelajaran itu sendiri guna untuk menyelesaikan beberapa topik bahasan yang sudah dirumuskan (Huda, 2013).

Kelebihan yang dimiliki model pembelajaran Probing-Prompting adalah: a) siswa dapat terlibat selama proses pembelajaran (aktif), b) meningkatkan hasil belajar, c) mendidik anak percaya pada dirinya sendiri, d) mendatangkan rasa bangga apabila kelompok/ orang lain tidak bisa mengerjakan soal yang telah kita rumuskan, e) membantu siswa mendapatkan pemahaman yang lebih baik.

Proses pembelajaran tidak akan terlepas dari adanya hubungan interaksi antara pendidik dan siswa. Aktivitas pembelajaran siswa bisa dirasakan dan terlihat apabila terjadi adanya suatu interaksi antara siswa dan pendidik dalam proses pembelajaran langsung (Supriyadi, 2011). Peran guru pada proses pembelajaran mempunyai tugas yang wajib harus dilakukan dengan memberikan pengetahuan dan pemahaman, mencontohkan sikap, perilaku dan nilai serta meningkatkan keterampilan guna menunjang peningkatan hasil belajar siswa. Pendidik bertanggung jawab untuk memantau segala aktivitas siswa yang terjadi di kelas dan membantu proses intelektual peserta didik agar semakin berkembang setiap harinya. Guru menyampaikan materi yang diajarkan merupakan salah satu dari aktivitas guru yang secara dinamis dalam segala fase untuk meningkatkan perkembangan pemahaman peserta didik pada saat proses pembelajaran (Dimyati \& Mudjiono, 2015).

Proses pembelajaran dilakukan oleh seorang guru dengan tujuan mencapai hasil belajar yang baik. Hasil belajar yang baik dapat dicapai apabila pembelajaran dilakukan secara optimal. Hasil belajar siswa merupakan kemampuan yang telah diperoleh siswa setelah mengikuti kegiatan belajar yang ada di sekolah, di keluarga maupun di masyarakat (Ahmad, 2014). Terdapat sepuluh faktor yang dapat mempengaruhi hasil belajar siswa 
Angga. Efektivitas Penggunaan Model Pembelajaran...

antara lain: kompetensi yang dimiliki oleh guru serta kondisi lingkungan sekitar masyarakat, suasana proses belajar mengajar, kompetensi, sikap dan kepribadian guru, teknik penyajian materi oleh pendidik, minat pada siswa, kemauan untuk belajar, bakat yang tersimpan pada anak, persiapan anak dalam belajar, dan intelektual siswa (Kristin, 2016). Dari kesepuluh faktor yang sudah dipaparkan oleh penulis beberapa sangat mempengaruhi hasil belajar seorang siswa yaitu intelektual siswa, persiapan anak dalam belajar dan bakat yang tersimpan pada diri anak. Faktor yang sebagian penyebabnya hampir sepenuhnya tergantung pada guru yaitu faktor kemampuan (kompetensi), suasana belajar dan kepribadian guru.

\section{METODE}

Penelitian kuantitatif digunakan untuk menguji hipotesis yang telah ditetapkan oleh peneliti, data yang diperoleh dari sampel atau populasi nantinya berupa angka dan dianalisis menggunakan uji statistik (Sugiono, 2015). Adapun sifat penelitian yang sudah diaplikasikan oleh peneliti yaitu penelitian eksperimen. Penelitian eksperimen itu sendiri merupakan penelitian yang bertujuan untuk mencari pengaruh suatu perlakuan terhadap yang lain dengan kondisi yang terkontrol. Peneliti mengaplikasikan preexperimental design pada penelitian yang dilakukan dengan bentuk one group pretestposttest. Teknik pengambil data menggunakan tes yang nantinya diberikan kepada sampel, tes pertama adalah pretest yang dimana tes ini diberikan sebelum diberi perlakuan, setelah itu diberikan tes yang kedua yaitu posttest yang dimana tes ini diberikan setelah sampel diberikan perlakuan oleh peneliti. Hasil dari posttest dibandingkan dengan prestest atau keadaan sebelum diberikan perlakuan sehingga data yang diperoleh merupakan hasil yang lebih akurat untuk dijadikan patokan hipotesis penelitian (Arikunto, 2013). Penelitian pre-experimental one-group pretest-posttest, pada tahap pertama yaitu menentukan subyek penelitian dan mengelompokkannya menjadi satu kelas. Tahap selanjutnya adalah memberikan pretest untuk mengukur hasil belajar siswa sebelum diberikan perlakuan model pembelajaran probing prompting. Kemudian, pada tahap akhir subyek penelitian diberikan posttest untuk mengukur hasil belajar siswa setelah diberikannya perlakuan.

Populasi penelitian ini adalah siswa kelas V SDN 1 Gamping dengan jumlah 17 siswa dan keseluruhan populasi dijadikan sampel karena teknik sampling yang 
Angga. Efektivitas Penggunaan Model Pembelajaran... digunakan adalah sampling jenuh. Teknik yang digunakan untuk mengumpulkan data yaitu observasi dan tes. Sebelum tes dibagikan kepada siswa, terlebih dahulu tes di uji coba validitas dan reliabilitas ke 25 siswa di SDN 3 Gamping tujuannya untuk mengetahui valid dan reliabelnya tes yang digunakan untuk penelitian. Analisis data dalam peelitian ini ada dua tahap, tahap pertama merupakan tahap prasyarat analisis data dengan menggunakan uji normalitas, rumus statistik yang digunakan untuk menguji normalitas yaitu chi-square sedangkan untuk uji homogenitas menggunakan rumus statistik yaitu lavene's test, kedua uji yang diolah oleh peneliti dibantu oleh aplikasi SPPS versi 21.0. Tahap kedua merupakan uji hipotesis yang digunakan untuk mengetahui efektifitas variabel bebas terhadap variabel terikat dengan menggunakan rumus statistik. Rumus statistik yang digunakan adalah uji independen t-test dengan dibantu aplikasi SPSS versi 21.0 (Soentoro, 2015). Berdasarkan sifat penelitian, metode analisis dan pengambilan sampel yang sudah dijabarkan di atas, maka peneliti menggunakan statistik untuk mengetahui kesimpulan data.

\section{HASIL}

Hasil penelitian yang telah dilakukan pada perhitungan uji validitas soal. Peneliti menggunakan data hasil tes yang dihitung dengan rumus korelasi product moment. Jika harga rxy > rtabel maka soal dikatakan valid dengan taraf signifikan 5\%.

Tabel 1. Uji Validitas

\begin{tabular}{|c|c|c|}
\hline Indikator & $\begin{array}{c}\text { Koefisien Korelasi } \\
\text { (r hitung) }\end{array}$ & Keterangan \\
\hline Soal 1 & 0,589 & Valid \\
\hline Soal 2 & 0,527 & Valid \\
\hline Soal 3 & 0,774 & Valid \\
\hline Soal 4 & 0,871 & Valid \\
\hline Soal 5 & 0,547 & Valid \\
\hline Soal 6 & 0,610 & Valid \\
\hline Soal 7 & 0,712 & Valid \\
\hline Soal 8 & 0,593 & Valid \\
\hline Soal 9 & 0,731 & Valid \\
\hline Soal 10 & 0,468 & Valid \\
\hline Soal 11 & 0,845 & Valid \\
\hline Soal 12 & 0,946 & Valid \\
\hline Soal 13 & 0,460 & Valid \\
\hline Soal 14 & 0,610 & Valid \\
\hline Soal 15 & 0,774 & Valid \\
\hline Soal 16 & 0,455 & Valid \\
\hline Soal 17 & 0,856 & Valid \\
\hline Soal 18 & 0,712 & \\
\hline
\end{tabular}


Angga. Efektivitas Penggunaan Model Pembelajaran...

\begin{tabular}{|c|c|c|}
\hline Soal 19 & 0,901 & Valid \\
\hline Soal 20 & 0,516 & Valid \\
\hline \multicolumn{2}{|c|}{ Keseluruhan butir soal dinyatakan valid } \\
\hline
\end{tabular}

Hasil uji validitas dengan menggunakan rumus korelasi product moment dengan dibantu aplikasi SPSS versi 21.0 didapatkan hasil kesuluruhan butir soal dinyatakan valid. Setelah hasil uji validitas diperoleh oleh peneliti maka selanjutnya melakukan uji reliabilitas merupakan uji yang dilakukan oleh peneliti untuk melihat keajegan suatu instrumen dalam penelitian, yang pada intinya instrument penelitian tersebut yang akan digunakan akan memberikan hasil yang tidak berubah-ubah. Hasil uji reliabilitas diperoleh sesuai dengan tabel dibawah ini.

Tabel 2. Uji Reliabilitas Variabel Penelitian

\begin{tabular}{|c|c|}
\hline Variabel Penelitian & Guttman Split-Half Coefficient \\
\hline Hasil Belajar siswa & 0,946 \\
\hline
\end{tabular}

Hasil reliabilitas dengan rumus guttman split-half coefficient dari data instrument tes yang diberikan kepada siswa diperoleh 0,946 sehingga bisa dikatakan instrument tes reliabel karena lebih dari 0,6 yang dijadikan patokan dari hasil yang diperoleh, setelah butir soal dinyatakan valid dan reliabel maka tes bisa digunakan untuk pengambilan data hasil belajar siswa.

Data yang diolah dalam penelitian berasal dari kedua tes yang telah diberikan kepada sample penelitian untuk melihat hasil belajar siswa terkait dengan adanya peningkatan yang signifikan atau tidak sesuai dengan hipotesis penelitian dan menjawab kesesuaian rumusan masalah peneliti.

Data hasil belajar tematik dari soal pretest dan posttest pada tema bangga sebagai bangsa Indonesia baik pada kelas V SDN 1 Gamping disajikan pada tabel berikut.

Tabel 3. Rata-Rata Hasil Belajar Siswa

\begin{tabular}{|c|c|c|c|}
\hline \multirow{2}{*}{ No } & \multirow{2}{*}{ Nilai } & \multicolumn{2}{|c|}{ Hasil Belajar Siswa } \\
\cline { 3 - 4 } & & Pretest & Posttest \\
\hline 1 & Rata-Rata & 66,2 & 76,7 \\
\hline 2 & Nilai Tertinggi & 85 & 90 \\
\hline 3 & Nilai Terendah & 45 & 60 \\
\hline
\end{tabular}




\section{Angga. Efektivitas Penggunaan Model Pembelajaran...}

Tabel diatas menjelaskan bahwasanya data hasil belajar kelas V SDN 1 Gamping diperoleh pada saat memberikan tes diawal sebelum perlakuan didapatkan nilai terendah 45 dan nilai tertinggi sebesar 60 dengan rata-rata nilainya adalah 66,2. Pada tes terakhir setelah mendapatkan perlakuan nilai terendah 60 dan nilai tertinggi 90 dengan rata-rata nilainya adalah 76,7.

Jika dilihat dari kedua tes yang diberikan diperoleh hasil yang signifikan karena dilihat dari rata-ratanya saja yang sudah berbeda, hasil yang didapatkan dari posttest lebih tinggi dari hasil pretest. Maka dari itu dengan adanya perlakuan maka hasil belajarpun bisa meningkat sesuai hipotesis penelitian. Data hasil yang didapatkan dari pengukuran hasil belajar siswa bisa terlihat di dalam diagram dibawah ini.

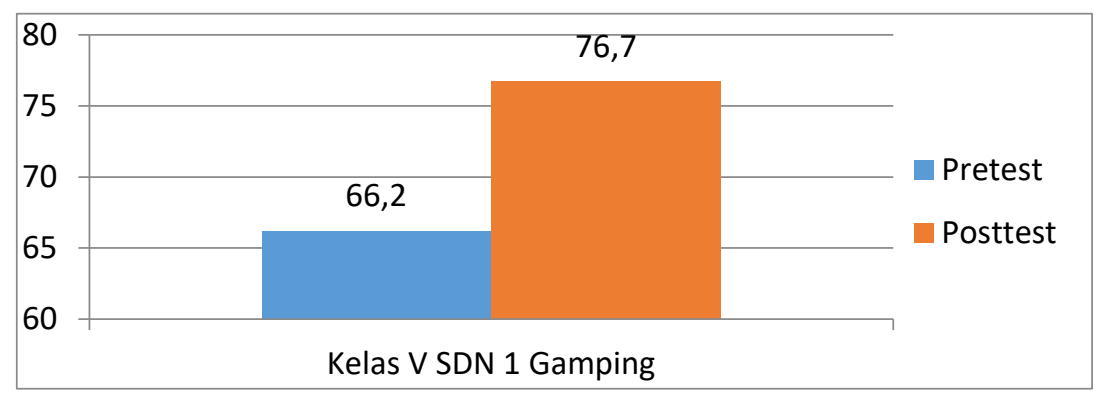

\section{Gambar 1. Persentase Nilai Rata-Rata Hasil Belajar Siswa}

Berdasarkan gambar 1 di atas, jika dilihat dari kedua hasil dapat disimpulkan bahwa terjadi peningkatan yang signifikan hasil belajar dengan selisih 10,5 pada siswa kelas V SDN 1 Gamping

Selanjutnya melakukan uji prasyarat penelitian, pertama menggunakan uji normalitas data yang diperoleh dari data hasil belajar siswa, Uji normalitas data tersebut dihitung dengan rumus statistik yaitu uji chi-square dengan kriteria jika signifikansi < 0,05, maka data tidak berdistribusi normal, jika nilai signifikansi $>0,05$, maka data berdistribusi normal. Adapun hasil uji normalitas data hasil belajar pada penelitian ini adalah sebagai berikut.

Tabel 4. Hasil Uji Normalitas Data Hasil Belajar Siswa

\begin{tabular}{|c|c|c|c|}
\hline \multirow{2}{*}{ Kelas } & Variabel & $\begin{array}{c}\text { Uji } \\
\text { chi-square }\end{array}$ & $\begin{array}{c}\text { Keterangan } \\
\left(\begin{array}{c}\text { Asymp. Sig. } \mathbf{~} \text { ( }) \\
\mathbf{0 , 0 5})\end{array}\right.\end{array}$ \\
\hline $\begin{array}{c}\text { Kelas V } \\
\text { SDN 1 Gamping }\end{array}$ & Pretest & 0,537 & Normal \\
\cline { 2 - 4 } & Posttest & 0,548 & Normal \\
\hline
\end{tabular}


Angga. Efektivitas Penggunaan Model Pembelajaran...

Tabel 4 data yang diperoleh dari kedua tes berdasarkan hasil pengujian menggunakan SPSS diperoleh nilai 0,537 dan 0,548. Dapat disimpulkan bahwa nilai Signifikansi (Sig.) > 0,05 yang berarti bahwa data pretest dan posttest pada kelas V berdistribusi normal.

Langkah kedua menggunakan Uji homogenitas data tersebut dihitung dengan menggunakan uji lavene's test. Adapun hasil uji homogenitas data hasil belajar bisa dilihat di tabel bawah ini.

Tabel 5. Hasil Uji Homogenitas Data Hasil Belajar Siswa

\begin{tabular}{|c|c|c|c|c|c|}
\hline & $\begin{array}{c}\text { Levene } \\
\text { Statistic }\end{array}$ & df1 & df2 & Sig. & $\begin{array}{c}\text { Keterangan } \\
\left(\begin{array}{c}\text { Asymp. Sig. }> \\
\text { 0,05) }\end{array}\right.\end{array}$ \\
\hline Pretest & 0,345 & 1 & 16 & 0,387 & Homogen \\
\hline Posttest & 0,057 & 1 & 16 & 0,651 & Homogen \\
\hline
\end{tabular}

Berdasarkan hasil yang diperoleh setelah melakukan pengujian menggunakan SPSS diketahui hasil belajar siswa pada pretest yaitu 0,387. Pada posttest hasil pengujian diketahui bahwa data hasil belajar siswa yaitu 0,651. Jika dibandingkan dengan nilai signifikan 0,05 maka data yang diperoleh lebih besar dari nilai 0,05 itu sendiri sehingga bisa dikatakan kedua tes hasil belajar yang diperoleh memiliki varian yang sama (homogen)

Selanjutnya melakukan uji hipotesis dengan menggunakan uji Independent tTest dari data hasil belajar sebelum diberikan perlakuan sesuai tabel yang ada dibawah ini.

Tabel 6. Hasil Uji Independent t-Test Data Pretest Hasil Belajar Siswa

\begin{tabular}{|l|c|c|c|c|}
\hline $\mathbf{t}_{\text {hitung }}$ & $\mathbf{t}_{\text {tabel }}$ & Df & Sig. (2-tailed) & $\mathbf{A}$ \\
\hline 1,141 & 2,119 & 16 & 0,268 & 0,05 \\
\hline
\end{tabular}

Tabel 6 menjelaskan bahwa data yang diperoleh dari rumus uji Independent tTest dapat diketahui $t_{\text {hitung }}$ untuk data pretest hasil belajar siswa sebesar 1,141 jika dibandingkan dengan tabel 2,119 dapat disimpulkan bahwa berarti Ho diterima dan Ha ditolak. Dengan demikian tidak ada perbedaan yang signifikan.

Hasil uji hipotesis data hasil belajar siswa pada posttest dapat dilihat pada tabel dibawah ini 
Angga. Efektivitas Penggunaan Model Pembelajaran...

Tabel 7. Hasil Uji Hipotesis Data Posttest Hasil Belajar Siswa

\begin{tabular}{|l|c|c|c|c|}
\hline $\mathbf{t}_{\text {hitung }}$ & $\mathbf{t}_{\text {tabel }}$ & Df & Sig. (2-tailed) & A \\
\hline 3,290 & 2,119 & 16 & 0,004 & 0,05 \\
\hline
\end{tabular}

Berdasarkan hasil uji Independent t-Test pada tabel 7 data posttest hasil belajar siswa dapat diketahui bahwa thitung sebesar 3,290 jika dibandingkan dengan $t_{\text {tabel }} 2,119$ maka dapat ditarik kesimpulan berarti Ho ditolak dan Ha diterima maka data dikatakan signifikan. Maka dengan melihat data yang diperoleh dengan menggunakan uji-t model pembelajaran Probing-Prompting efektif untuk meningkatkan hasil belajar tematik bagi siswa kelas V Sekolah Dasar.

\section{PEMBAHASAN}

Instrumen tes sebelum diberikan kepada sample maka butir soal di validasikan terlebih dahulu menggunakan aplikasi SPSS versi 21.0 dengan hasil seluruh butir soal valid. Langkah selanjutnya yaitu menghitung reliabilitas butir soal tersebut dengan menggunakan rumus Guttman Split-Half Coefficient nilai yang diperoleh 0,946 maka dinyatakan valid karena lebih dari 0,6 . Setelah butir soal sudah dinyatakan valid dan reliabel maka tes diberikan kepada peserta didik, tes diberikan sebelum dan sesudah perlakuan dengan hasil yang diperoleh untuk rata-rata nilai pretest adalah 66,2 sedangkan posttest rata-rata nilainya adalah 76,7 . Untuk mengetahui persebaran data hasil belajar normal dan homogeny maka diuji menggunakan rumus uji chi-square dan uji lavene's test dengan hasil yang diperoleh untuk normalitas sebesar 0,537 dan 0,548 maka dinyatakan persebaran data hasil belajar normal, sedangkan hasil yang diperoleh untuk uji homogenitas sebesar yaitu 0,387 dan 0,651 maka dinyatakan persebaran data hasil belajar homogeny. Pada hasil analisis nilai rata-rata pretest dan posttest hasil belajar siswa terdapat perbedaan yang signifikan sebesar 10,5. Dari selisih nilai rata-rata tersebut, dapat dikatakan adanya perbedaan hasil belajar siswa kelas V SDN 1 Gamping diperkuat oleh hasil uji Independent t-Test yaitu diperoleh thitung 3,290 (df 16) $>t_{\text {tabel }}$ 2,119 (df 16). Hal ini menunjukkan bahwa ada perbedaan yang signifikan hasil belajar siswa. Jadi dapat disimpulkan bahwa model pembelajaran Probing-Prompting efektif meningkatkan hasil belajar siswa. 
Angga. Efektivitas Penggunaan Model Pembelajaran...

\section{SIMPULAN}

Berdasarkan kesimpulan penelitian model pembelajaran Probing-Prompting efektif meningkatkan hasil belajar siswa dalam pembelajaran tematik siswa kelas $\mathrm{V}$ Sekolah Dasar dengan menganalisis nilai rata-rata pretest dan posttest hasil belajar siswa sehingga hasil yang didapatkan perbedaan yang signifikan. Dari nilai rata-rata tersebut, hasil belajar siswa dari nilai pretest dan posttest dihitung menggunakan SPSS dengan uji Independent t-Test untuk memperkuat analisis hipotesis peneliti, hasil yang diperoleh yaitu thitung $3,290>\mathrm{t}_{\text {tabel }} 2,119$ maka dinyatakan efektif

Untuk tindak lanjut kedepannya peneliti menyarankan kepada:

1. Guru SDN 1 Gamping, Trenggalek

Guru SDN 1 Gamping diharapkan lebih mengeksplorasi model pembelajaran Probing Prompting sebagai referensi dalam proses pembelajaran agar lebih aktif dan inovatif untuk diterapkan dalam pembelajaran tematik.

2. Bagi Siswa

Diharapkan dari hasil penelitian siswa dapat lebih aktif dalam proses pembelajaran dan dapat meningkatkan hasil belajar, serta dapat meningkatkan berdiskusi siswa di kelas dengan teman sebayanya dan guru kelas.

3. Bagi Sekolah

Diharapkan dari hasil penelitian dapat menjadi masukan untuk meningkatkan kualitas pembelajaran di sekolah dalam rangka meningkatkan hasil belajar dan menentukan kebijakan sekolah dalam penggunaan model pembelajaran pada tiap pembelajaran, serta dapat digunakan sebagai pelatihan bagi guruguru yang ada di sekolah tentang model pembelajaran.

4. Peneliti lainnya

Peneliti lain diharapkan dapat mengembangkan model pembelajaran Probing Prompting terhadap hasil belajar guna meningkatkan prestasi siswa secara akademik dan non akademik.

\section{DAFTAR RUJUKAN}

Abdurokhim, Mohamad. 2015. Keefektifan Model Probing-Prompting Dalam Pembelajaran Sejarah Uang Pada Siswa Kelas III Sd Negeri Kepandean 3 
Angga. Efektivitas Penggunaan Model Pembelajaran...

Kabupaten Tegal. Skripsi. Fakultas Ilmu Penididkan, Pendidikan Guru Sekolah

Dasar, UNNES, Semarang. diakses 22 Maret 2021.

Arikunto, Suharsimi. 2013. Prosedur Penelitian Suatu Pendekatan Praktik. Jakarta: Rineka Cipta.

Artawan, Ketut Agus., Gading, I Ketut., Dibia, I Ketut. 2017. Pengaruh Model Pembelajaran Probing - Prompting Terhadap Hasil Belajar IPA Pada Siswa Kelas V Sekolah Dasar. UNDIKSHA: JJPGSD, 5(2), 1-10. doi: http://dx.doi.org/10.23887/jjpgsd.v5i2.10916.

Dimyati \& Mudjiono. 2015. Belajar dan Pembelajaran. Jakarta: Rineka Cipta.

Firosalia, Kristin. 2016. Analisis Model Pembelajaran Discovery Learning Dalam Meningkatkan Hasil Belajar Siswa SD. Jurnal Pendidikan Dasar PerKhasa: Jurnal Penelitian Pendidikan Dasar , 2(1), 90-98. diakses 22 Maret 2021.

Hamdu, Ghullam., Agustina, Lisa. 2012. Pengaruh Motivasi Belajar Siswa Terhadap Pestasi Belajar Ipa Di Sekolah Dasar. Universitas Pendidikan Indonesia: Jurnal Penelitian Pendidikan, 11(1), 36-47, diakses 22 Maret 2021.

Hendrawan, Teguh., Kasdi, Aminuddin., Sukartiningsih, Wahyu. 2019. Pengaruh Model Pembelajaran Probing-Prompting Terhadap Hasil Belajar Siswa Di Kelas V Sekolah Dasar. Jurnal Review Pendidikan Dasar: Jurnal Kajian Penelitian dan Hasil Penelitian, 5(3), 24-33. doi: http://dx.doi.org/10.26740/jrpd.v5n3.p10841091.

Huda, Miftahul. 2013. Model-model Pengajaran dan Pembelajaran. Yogyakarta: Pustaka Pelajar.

Kusuma, Yanti Yandri. 2020. Penerapan Model Pembelajaran Probingpromting Untuk Meningkatkan Aktivitas Belajar Pada Mata Pelajaran Pkn Di Sekolah Dasar. Universitas Pahlawan: Jurnal Review Pendidikan dan Pengajaran, 3(1),34-42, diakses 22 Maret 2021.

Soentoro, Ali Idris. 2015. Cara Mudah Belajar Metodologi Penelitian Dengan Aplikasi Statistika: Edisi Pertama, Depok: PT Taramedia Bakti Persada.

Sugiyono. 2015. Metode Penelitian Pendidikan Pendekatan Kuantitatif, Kualitatif, dan $R \& D$. Bandung : Alfabeta.

Supriyadi. 2011. Strategi Belajar Mengajar. Yogyakarta: Cakrawala Ilmu. 
Angga. Efektivitas Penggunaan Model Pembelajaran...

Susanto. Ahmad. 2014. Pengembangan Pembelajaran IPS di Sekolah Dasar. Jakarta: Prenada Media Group.

Thobroni. 2015. Belajar dan Pembelajaran:Teori dan Praktik. Yogyakarta: Ar-Ruz Media.

Trianto. 2011. Model Pembelajaran Terpadu. Jakarta: Bumi Aksara. 